\title{
Biometric Aspects and Seasonal Metal Concentration in Crassostrea rhizophorae in São Paulo River Estuary, Brazil
}

\author{
Alexandre Dacorso Daltro Milazzo ${ }^{\mathrm{a} *}$, Eduardo Gomes Vieira de Melo ${ }^{\mathrm{b}}$, Eduardo Passos Lima ${ }^{\mathrm{c}}$, \\ Manoel Jerônimo Moreira da CRUZ \\ $a^{*}$ Geoscience Institute, Departament of Geology, Universidade Federal da Bahia (UFBA), Campus Ondina, \\ 40170-290 Salvador-BA, Brasil. \\ ${ }^{b}$ Geoscience Institute, Departament of Geochemistry, Universidade Federal da Bahia (UFBA), Campus \\ Ondina, 40170-290 Salvador-BA, Brasil. \\ ${ }^{c}$ University Norte do Paraná (UNOPAR), Av. Santiago de Compostela, 216 - Parque Bela Vista, CEP: 40279 - \\ 150 Salvador-BA, Brasil. \\ ${ }^{d}$ Associeted Professor III, Geoscience Institute, Departament of Geology, Universidade Federal da Bahia \\ (UFBA), Campus Ondina, 40170-290 Salvador-BA, Brasil.
}

*Corresponding Author: Alexandre Dacorso Daltro Milazzo, Geoscience Institute, Departament of Geology, Universidade Federal da Bahia (UFBA), Campus Ondina, 40170-290 Salvador-BA, Brasil.

\begin{abstract}
Estuarine environments and its mangrove forests have ecological importance by serving as habitat for many species. Because the human activities, the levels of metals in these zones have increased and contributed with effects on many organisms, constituting a risk to environmental. The metal concentration the knowledge about their geochemical behavior is a good tool to monitoring the quality of estuarine environments. This research choose the oyster Crassostrea rhizophorae to measure the bioconcentration of metals ( $\mathrm{Fe}, \mathrm{Zn}, \mathrm{Mn}, \mathrm{Cu}, \mathrm{Ni}$ and $\mathrm{Al}$ ) and the bioavailability in surface water and sediments in a estuarine zone in different seasons of the year. The highest metals concentrations in the water were during dry season, in sediment and biota the highest concentration were in rainy season. Zn and Fe were associated with the oysters growth. The values of metals changed between seasons and some metallic elements could be responsible for growth difference in the oysters.
\end{abstract}

Keywords: Estuarine, metals, oyster, seasonality.

\section{INTRODUCTION}

Estuarine environments has large importance in a perpetuation of species which also serve as habitat for different kind of organisms and many animals found there their foods. With mangrove forests the estuarine zones provide excellent conditions for different species of animals like fishes, birds, reptiles and mammals, where them can find good environments for their survival, protection and reproduction, therefore, zones of large biological productivity (Campana et al., 2005; Onofre et al., 2007).

In estuarine zones the environmental conditions are very especial, which make them also sensitive to disturbances like pollution (Strady et al., 2011). And the difference between low and high tide level of sea make the estuarine dynamic too much complex (Onofre et al., 2007; Nizoli and Luiz-Silva, 2009; Strady et al., 2011).

Due to the fact of estuarine zones are very dynamic, physicochemical process which happens throughout the year can influence the geochemistry of metallic elements, changing the behavior and bioavailability of metals on surface waters and sediments during the different season of the year (Vincente-Martorell et al., 2009; Campana et al., 2005).

Anomalies of trace metal accumulation in mollusks can makes with them have problems in their develops, body size and reproductive cycle for example, and it can cause serious problems in their life (Boyden 1974; Shulkin et al., 2003). Seasonal conditions in the environment may cause different bioavailability of metals for the biota (Páez-Osuna et al., 1995). 
In estuarine environments we can find the Crassostrea rhizophorae (Guilding, 1828), a species of bivalve mollusks, from family Ostreidae, sessile and filters-feeder organisms that usually accumulate pollutants in their tissue. Popularly known as the mangrove oyster, they are also easily sampled, are of reasonable size, sedentary and have a long life span, which makes these animals excellent bioindicators and/or biomonitors (Phillips, 1977; Nascimento et al., 1980; Silva et al., 2006).

The Sao Paulo river estuary, where that specie is usually used as food by local people and by local fisherman like economic activities as well, of fundamental importance for the local people has been affected by many human activities, such as contamination by chemical industries, which have contributed to the deterioration of the estuary (Carvalho, 2007).

Studies about animals size in estuarine environments can provide important information about the real condition of quality related with metal concentrations and as well as how metal concentration can affect the develops of these animals. However, physicochemical parameters on surface waters and sediments also can influence in the growth of these animals (Quayle, 1969; Nascimento et al., 1980; Shulkin et al., 2003).

In this context, we developed this study aimed to check the biometric characteristics of Crassostrea rhizophorae, as well as the metal concentration $(\mathrm{Zn}, \mathrm{Mn}, \mathrm{Cu}, \mathrm{Fe}, \mathrm{Ni}$ and $\mathrm{Al}$ ), in surface water, sediment and also in biota in the Sao Paulo river estuary, Todos os Santos Bay, Bahia, Brazil, in two different seasons (dry and rainy). In addiction the physicochemical parameters also were verified to make correlations with the values found about bioavailability and bioconcentration of metals in the environment and mollusks.

\section{MATERIAL AND MethodS}

\subsection{Studied Area}

This study was carried out in the Sao Paulo river estuary, a river that has its outlet in the Todos os Santos Bay, within the coordinates of $38^{\circ} 35^{\prime} 0^{\prime \prime}$ ' and $38^{\circ} 30^{\prime} 30^{\prime \prime} \mathrm{W}$ and $12^{\circ} 45^{\prime} 0^{\prime \prime}$ and $12^{\circ} 41^{\prime} 0^{\prime \prime} \mathrm{S}$ (Figure 1).

That estuarine zone, where a magnificent mangrove system develops, has a fundamental importance to the local food chain and to the livelihood of many of the inhabitants of the region. This estuarine ecosystem has been affected by many human activities, such as contamination by chemical industries, which have contributed to the deterioration of the estuary (Carvalho, 2007).

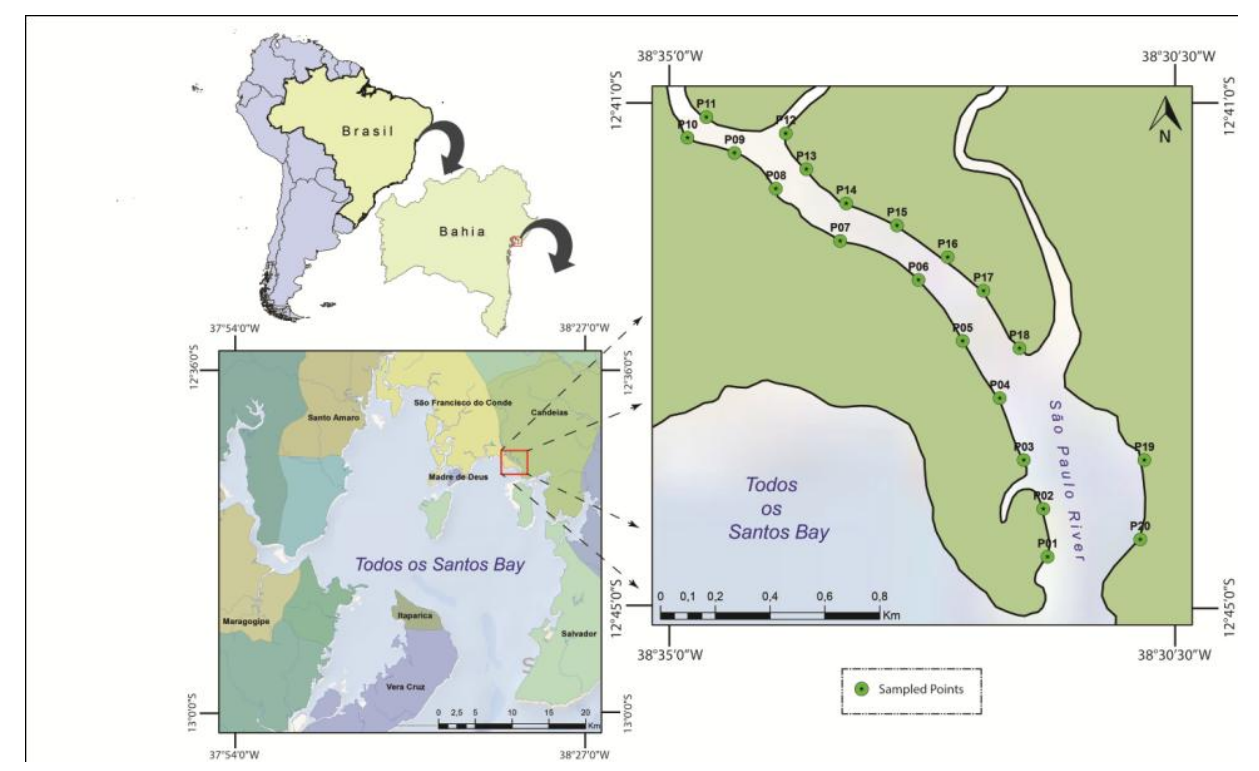

Figue. 1. Map of the studied area and sampling points.

The São Paulo river estuary, located in the Todos os Santos Bay, where a magnificent mangrove ecosystem develops, has a fundamental importance to the local food chain and to the livelihood of many of the inhabitants of the region. This estuarine ecosystem has been affected by many human activities, such as contamination by chemical industries, which have contributed to the deterioration of the estuary (Carvalho, 2007). 
Geologically, this region is included in the sedimentary basin of the Reconcavo Baiano. The climate is tropical-humid and presents a remarkable seasonal cycle. Rainfall in this region is around 300 $\mathrm{mm} /$ month between April and June, characterizing the wettest period. Between January and March, the rain is less intense and well distributed with a precipitation of around $125 \mathrm{~mm} / \mathrm{month}$ and an average annual of temperature of about $25^{\circ} \mathrm{C}$ (Kirimure, 2015). (Figure 2).
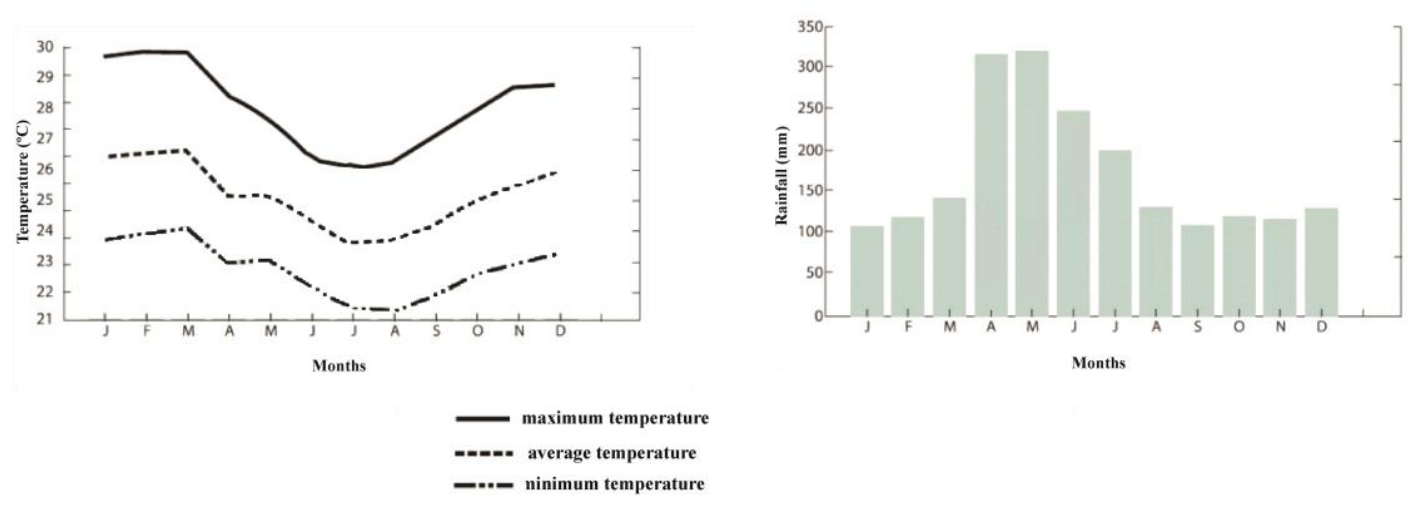

Figure 2. Seasonal variation of temperature and rainfall in Todos os Santos Bay.

The economic activities in this regions are considered as industrial and there have been cases of oil spills resulting from leakages, as well as contributions from industrial and domestics effluents from municipalities around the region (Jesus, 2011).

\subsection{Sampling Sites}

The field work was carried out seasonally in two periods, in the dry $(03 / 03 / 2010)$ and in the rainy (13/08/2010) seasons. Sampling occurred during the low tide in both seasons, also taking into account the variation according to the tidal period ( $0.2 \mathrm{~m}$ in both seasons).

Sediment, surface water and mollusks samples were obtained from 20 points (a representative number for the statistical analysis), 10 on each side in the region of mouth of the Sao Paulo river estuary, with a spatial difference of approximately $100 \mathrm{~m}$ between each point as a safe apace, since the organisms used in the study as sessile. The sampling points were randomly defined in order to avoid any bias in the results. The coordinates of each sampling point were obtained using a Global Positioning System device (GPS).

\subsection{Water Collection and Analysis}

Surface waters were sampled $(0-20 \mathrm{~cm})$ using previously decontaminated $500 \mathrm{ml}$ polyethylene bottles in each point. The samples were kept in coolers at a temperature of approximately $4^{\circ} \mathrm{C}$ until arrival at the laboratory. At the laboratory, the water samples were acidified with $\mathrm{HNO}_{3}$ (ACS ISO MERCK, $65 \%$, for analysis), following a standard of $1 \%$ relative to the total volume of each sample (Carvalho, 2007). These samples were used to analyze metal components according to the ASTM (1992) methodology, which consist of procedures for the analyses performed in water. Physicochemical parameters ( $\mathrm{pH}, \mathrm{Eh}$, temperature and salinity) were monitored in each of the sample points. For $\mathrm{pH}$, Eh and temperature, a $\mathrm{pH}-\mathrm{meter} / \mathrm{mV}$ Handylab1 Schott Glaswerke Mainz was used. For salinity measurement, a portable refractometer Atogo S/Mill-E was used, and for dissolved oxygen determination a multiparameter water/Manta 2.

Samples $(100 \mathrm{ml})$ for total metals were transferred to a beaker, and $10 \mathrm{ml}$ of nitric acid $\left(\mathrm{HNO}_{3}\right)$ was added. The beakers were later placed on a hot plate, until the volume was reduced to approximately $20 \mathrm{ml}$. After cooling, the fraction was transferred to a volumetric flask of $25 \mathrm{ml}$ for further metal determination.

\subsection{Sediment Collection and Analysis}

For the sediments cores, approximately $300 \mathrm{~g}$ were sampled from the surface $(0-10 \mathrm{~cm})$. These samples were stored in polyethylene packages, with a certain amount of water from the sampling site to preserve their characteristics. The samples were placed in coolers with ice to maintain a temperature of $4^{\circ} \mathrm{C}$, according to the methodology described by Jesus et al. (2003). 
Once the cores were properly stored and labeled, they were taken to the laboratory, where analysis of metals, particle size (classified as sand, silt and clay), and organic matter were carried out.

The microwave oven partial extraction technique was performed for the digestion of sediments, according to the D 5258-92 methodology from Standard Practice for Acid-Extraction of Elements from Sediments Using Closed Vessel Microwave Heating (ASTM, 1992), adapted to the manual of the No. 11 equipment (Provecto DGT 100 plus Microwave Manual). The method consisted of weighting $1.0 \mathrm{~g}$ of the dry sediment sample, at total fraction, and adding $10 \mathrm{ml}$ of $\mathrm{HNO}_{3}$ (ACS ISO MERCK, 65\%, for analysis). After extraction, the samples were passed through a quantitative filter $(0.80 \mu \mathrm{m})$, diluted in a volumetric flask of $50 \mathrm{ml}$ with deionized water and stored in a plastic flasks of $100 \mathrm{ml}$ bottle for metal analysis.

\subsection{Mollusks Collection and Analysis}

The biota was sampled at the same sampling points as the sediment and water. A total of 16 specimens of $C$. rhizophorae was gathered at each sampling point, through active visual search. The specimens were maintained in polyethylene bags, transported and kept in coolers with ice. Twelve individuals of each sampling point were randomly chosen in the laboratory for the analysis. The body size of each individual was measured and weighed. The measurement of length and width were obtained based on the distance between posterior and anterior axle. After that, the individuals were weighted with the shell and the tissue, after weight, the tissue was retired and the shell was weighted again, to obtain the weight of the tissue. Then the tissue of animals was freeze-dried for the procedures of digestion and metal analysis.

The method for the analysis of metals consisted of weighting $0.5 \mathrm{~g}$ of crushed tissue (dry weight), in which $5 \mathrm{ml} \mathrm{HNO}_{3}$ (ACS ISO MERCK, 65\%, for analysis), and $3 \mathrm{ml}$ of concentrated hydrogen peroxide $\left(\mathrm{H}_{2} \mathrm{O}_{2}\right)$ were added, according to the methodology adapted from the manual of equipment No. 24, Provecto DGT 100 plus Microwave Manual. The digested samples were measured in a volumetric flask of $25 \mathrm{ml}$ with deionized water and stored in plastic flasks of $30 \mathrm{ml}$ for further determination of metal contends.

Chemical analysis of the digestion of metals from different matrices were performed at the Laboratory of Petroleum Studies (LEPETRO), at the Center of Environment Studies (NEA) located at the Institute of Geoscience of the Federal University of Bahia (UFBA).

The quality control of the samples was carried out using duplicates (20\% of total samples) and triplicates (10\% of total samples), while maintaining acceptable accuracy and precision in the analysis by the estimated experimental error, in addition to blank samples for each matrix.

The concentration of metals in surface water, sediment and mollusk samples was determined in a Flame Atomic Absorption Spectrophotometer (FAAS), with detection limits of Fe: $0.27 \mathrm{mg} \mathrm{kg}^{-1} ; \mathrm{Zn}$ : $0.03 \mathrm{mg} \mathrm{kg}^{-1}$; Mn: $0.01 \mathrm{mg} \mathrm{kg}^{-1}$; Cu: $0.02 \mathrm{mg} \mathrm{kg}^{-1}$; Ni: $0.05 \mathrm{mg} \mathrm{kg}^{-1}$; Al: $0.5 \mathrm{mg} \mathrm{kg}^{-1}$.

The samples were prepared according to the analytical procedures used to perform the Certified Reference Material (Estuarine Water CRM SLEW 3, Canada/Stream Sediments CRM STSD-4, Canada and Oyster Tissue CRM NIST 1566, USA) for quality control.

Comparison of metals concentrations obtained with the Certified Reference Material (Table 1) showed that agreement was good, and all analysis can be considered satisfactory.

Table 1. Certified Reference Material values for Estuarine Water ( $\left.\mu \mathrm{g} l^{-1}\right)$, Stream Sediments $\left(\mathrm{mg} \mathrm{kg}^{-1}\right)$ and Oyster Tissue $\left(\mathrm{mg} \mathrm{kg}^{-1}\right)$.

\begin{tabular}{|l|l|l|l|}
\hline Metals & $\begin{array}{l}\text { 1. Estuarine Water CRM } \\
\text { SLEW 3 }\left(\mu \mathrm{g} \mathrm{l}^{-1}\right)\end{array}$ & $\begin{array}{l}\text { 2. Stream Sediments } \\
\text { CRM STSD-4 }\left(\mathrm{mg} \mathrm{kg}^{-1}\right)\end{array}$ & $\begin{array}{l}\text { 3. Oyster Tissue CRM } \\
\text { NIST 1566 }\left(\mathrm{mg} \mathrm{kg}^{-1}\right)\end{array}$ \\
\hline $\mathrm{Fe}$ & $0.568 \pm 0.059$ & $2.6(\%)$ & $205.8 \pm 6.8$ \\
\hline $\mathrm{Zn}$ & $0.201 \pm 0.037$ & 82 & $1424 \pm 46$ \\
\hline $\mathrm{Mn}$ & $1.61 \pm 0.22$ & 1200 & $18.5 \pm 0.2$ \\
\hline $\mathrm{Cu}$ & $1.55 \pm 0.12$ & 66 & $71.6 \pm 1.6$ \\
\hline $\mathrm{Ni}$ & $1.23 \pm 0.07$ & 23 & $1.04 \pm 0.09$ \\
\hline $\mathrm{Al}$ & $*$ & $*$ & $*$ \\
\hline
\end{tabular}

* Values not certified. 
${ }^{1}$ National Research Council Canada - SLEW 3.

${ }^{2}$ Stream Sediment Reference Materials, Canada.

${ }^{3}$ National Institute of Starndards and Tecnology, USA.

\subsection{Statistical Analysis}

To understand the variation of parameters studied and the metal behavior in the three matrices, the Office Excel 2003 software was used to obtain Box-Plots of physicochemical parameters as well as the graphs to show biometric data of mollusks studied and the STATISTCIA 7 software was used to observe summary statistics and trends of metal behavior and their relationships with surface water, sediment and biota, by means of the Principal Component Analysis (PCA).

\section{RESUlts}

As a total, 480 individuals of $C$. rhizophorae were analyzed, 240 in each season (dry and rainy). The biometric values of the mollusks had a small difference between both periods analyzed (dry and rainy seasons). The length between both periods had an average of $5.03 \mathrm{~cm}$ (dry) and $5.18 \mathrm{~cm}$ (rainy), the width had the average of $3.94 \mathrm{~cm}$ (dry) and $4.17 \mathrm{~cm}$ (rainy) and the weight values for mollusks tissues were $4.28 \mathrm{~g}$ (dry) and $4.92 \mathrm{~g}$ (rainy) (Table 2). As we also can see in the table 2, the maximum value for the length was $5.52 \mathrm{~cm}$ (dry) and in the rainy season was $5.68 \mathrm{~cm}$. About the width, the maximum was $5.89 \mathrm{~cm}$ in dry season and $5.07 \mathrm{~cm}$ in the rainy season. For the tissues weight the maximum values was $5.32 \mathrm{~g}$ in dry season and in the rainy season, the maximum value was $7.24 \mathrm{~g}$.

When we compare the biometric data between the sampled points in the same season, we also found a small amplitude. During the dry season, the length had a variation of $1.43 \mathrm{~cm}$ and $2.63 \mathrm{~cm}$ for the width. In the rainy season the length had a variation of $1.01 \mathrm{~cm}$ and $1.40 \mathrm{~cm}$ for the width. When we compare the weight tissues along the sampled points in one only season, we can see a small difference between the minimum and maximum values. In the dry season the extreme values were $2.68 \mathrm{~g}$ (minimum) and $5.32 \mathrm{~g}$ (maximum), and $3.31 \mathrm{~g}$ (minimum) and $7.24 \mathrm{~g}$ (maximum) during the rainy season (Table 2).

Analyzing the figure $3 \mathrm{a}$ we can see during the dry season that mostly organisms are concentrated between 4.5 and $5.0 \mathrm{~cm}$ of length, with 58 individuals, which represents $24.1 \%$ of total mollusks. If we compare with the rainy season, $19.6 \%$ of individuals, 47 specimens, were concentrated between 4.5 and $5.0 \mathrm{~cm}$ of length and the mostly of mollusks, 65 specimens, which represents $27.1 \%$ were in rate between $5.0<\mathrm{X} \leq 6.0 \mathrm{~cm}$.

In the figure $3 \mathrm{~b}$ we can see the results for the width and notice that during the rainy season $32.1 \%$ of mollusks were in the rate between $4.0<X \leq 4.5 \mathrm{~cm}$, which represents 77 specimens. On the other hand, in the dry season, the mostly mollusks stayed between $3.5<\mathrm{X} \leq 4.0 \mathrm{~cm}$, with 68 individuals, which represents $28.3 \%$.

Analyzing the results for the weight in both seasons (Figure 4) and comparing the values, some differences can be observed. In the sampled point 10 for example, during the rainy season (4b), the average of weight was $7.2 \mathrm{~g}$ and during the dry season (4a) was $4.4 \mathrm{~g}$, almost $3 \mathrm{~g}$ of difference, what is relatively representative considering this specie of mollusks. In the sampled point 17 we also can see a little difference, in the rainy season (4b) the average was $6.4 \mathrm{~g}$ while in the dry season (4a) was $4.3 \mathrm{~g}, 2.1 \mathrm{~g}$ of variation.

Table 2. Biometric data (Length, Width $(\mathrm{cm})$ and Weight $(\mathrm{g})$ ) of C. rhizophorae between season (dry and rainy) in São Paulo river estuary (average, min., and max.).

\begin{tabular}{|c|c|c|c|c|c|c|}
\hline \multirow{3}{*}{ Sampled Points } & \multicolumn{6}{|c|}{ Biometric data / season } \\
\cline { 2 - 7 } & \multicolumn{2}{|c|}{ Length } & \multicolumn{2}{c|}{ Width } & \multicolumn{2}{c|}{ Weight } \\
\cline { 2 - 7 } & Dry & Rainy & Dry & Rainy & Dry & Rainy \\
\cline { 2 - 7 } & 5.03 & 5.37 & 3.87 & 4.44 & 4.37 & 4.49 \\
P 1 & $3.77-6.91$ & $4.14-6.95$ & $2.85-4.87$ & $3.21-7.22$ & $1.61-16.63$ & $2.39-8.57$ \\
\hline \multirow{2}{*}{ P 2 } & 5.02 & 5.61 & 4.33 & 3.95 & 4.64 & 5.00 \\
& $4.01-6.43$ & $4.49-7.15$ & $2.57-6.14$ & $2.94-5.53$ & $2.66-6.65$ & $2.06-9.05$ \\
\hline \multirow{2}{*}{ P 3 } & 5.40 & 5.14 & 3.73 & 4.28 & 3.88 & 4.76 \\
& $4.11-6.42$ & $4.00-6.19$ & $3.04-5.12$ & $3.27-5.38$ & $0.89-7.92$ & $3.30-7.15$ \\
\hline \multirow{2}{*}{ P 4 } & 4.86 & 4.69 & 4.22 & 3.66 & 5.13 & 3.31 \\
& $3.53-6.75$ & $3.62-6.17$ & $2.90-5.40$ & $3.06-4.56$ & $1.73-11.57$ & $1.78-6.82$ \\
\hline
\end{tabular}


Biometric Aspects and Seasonal Metal Concentration in Crassostrea rhizophorae in São Paulo River Estuary, Brazil

\begin{tabular}{|c|c|c|c|c|c|c|}
\hline P 5 & $\begin{array}{c}4.61 \\
3.61-5.51\end{array}$ & $\begin{array}{c}4.89 \\
3.50-5.69\end{array}$ & $\begin{array}{c}3.37 \\
2.54-4.20\end{array}$ & $\begin{array}{c}4.11 \\
3.30-5.06\end{array}$ & $\begin{array}{c}3.47 \\
1.02-5.82\end{array}$ & $\begin{array}{c}4.80 \\
2.63-7.62\end{array}$ \\
\hline P 6 & $\begin{array}{c}4.58 \\
3.01-6.02\end{array}$ & $\begin{array}{c}5.68 \\
4.62-6.64\end{array}$ & $\begin{array}{c}5.89 \\
2.97-3.05\end{array}$ & $\begin{array}{c}3.98 \\
2.67-5.13\end{array}$ & $\begin{array}{c}3.87 \\
2.52-6.75\end{array}$ & $\begin{array}{c}5.56 \\
2.70-9.21\end{array}$ \\
\hline P 7 & $\begin{array}{c}5.50 \\
3.67-8.19\end{array}$ & $\begin{array}{c}5.29 \\
4.39-6.78\end{array}$ & $\begin{array}{c}3.96 \\
3.28-5.22\end{array}$ & $\begin{array}{c}4.21 \\
3.66-4.69\end{array}$ & $\begin{array}{c}4.80 \\
1.80-9.62\end{array}$ & $\begin{array}{c}5.06 \\
2.49-7.93\end{array}$ \\
\hline P 8 & $\begin{array}{c}5.52 \\
3.96-6.98 \\
\end{array}$ & $\begin{array}{c}5.34 \\
4.34-7.31 \\
\end{array}$ & $\begin{array}{c}3.83 \\
2.35-5.71 \\
\end{array}$ & $\begin{array}{c}4.34 \\
3.84-5.00 \\
\end{array}$ & $\begin{array}{c}5.32 \\
1.56-11.39 \\
\end{array}$ & $\begin{array}{c}4.68 \\
3.23-7.07 \\
\end{array}$ \\
\hline P 9 & $\begin{array}{c}5.42 \\
4.15-8.23 \\
\end{array}$ & $\begin{array}{c}5.30 \\
4.34-6.09 \\
\end{array}$ & $\begin{array}{c}4.01 \\
3.18-5.42 \\
\end{array}$ & $\begin{array}{c}3.94 \\
2.73-5.13 \\
\end{array}$ & $\begin{array}{c}4.56 \\
2.26-11.70 \\
\end{array}$ & $\begin{array}{c}5.12 \\
1.53-7.37 \\
\end{array}$ \\
\hline P 10 & $\begin{array}{c}4.96 \\
3.95-6.21\end{array}$ & $\begin{array}{c}5.42 \\
4.15-7.15\end{array}$ & $\begin{array}{c}3.95 \\
3.02-4.62\end{array}$ & $\begin{array}{c}4.31 \\
2.99-5.46\end{array}$ & $\begin{array}{c}4.41 \\
2.06-7.94\end{array}$ & $\begin{array}{c}7.24 \\
2.73-13.60\end{array}$ \\
\hline P 11 & $\begin{array}{c}5.33 \\
4.01-7.19\end{array}$ & $\begin{array}{c}5.48 \\
3.91-6.67\end{array}$ & $\begin{array}{c}3.79 \\
2.71-4.85\end{array}$ & $\begin{array}{c}4.43 \\
3.28-5.05\end{array}$ & $\begin{array}{c}3.90 \\
0.44-8.26\end{array}$ & $\begin{array}{c}5.41 \\
1.75-8.10\end{array}$ \\
\hline P 12 & $\begin{array}{c}5.31 \\
3.20-6.98 \\
\end{array}$ & $\begin{array}{c}5.31 \\
4.24-6.69 \\
\end{array}$ & $\begin{array}{c}3.83 \\
3.10-5.05 \\
\end{array}$ & $\begin{array}{c}5.07 \\
4.05-8.50 \\
\end{array}$ & $\begin{array}{c}5.19 \\
3.13-8.42 \\
\end{array}$ & $\begin{array}{c}6.55 \\
1.96-12.63 \\
\end{array}$ \\
\hline P 13 & $\begin{array}{c}5.26 \\
3.39-6.68\end{array}$ & $\begin{array}{c}5.32 \\
3.83-6.46\end{array}$ & $\begin{array}{c}4.13 \\
2.64-5.30\end{array}$ & $\begin{array}{c}4.21 \\
3.12-5.13\end{array}$ & $\begin{array}{c}6.34 \\
4.43-8.02\end{array}$ & $\begin{array}{c}5.31 \\
2.40-9.06\end{array}$ \\
\hline P 14 & $\begin{array}{c}5.24 \\
4.36-6.30 \\
\end{array}$ & $\begin{array}{c}4.98 \\
3.67-6.75 \\
\end{array}$ & $\begin{array}{c}4.19 \\
3.21-5.32 \\
\end{array}$ & $\begin{array}{c}4.16 \\
3.36-5.40 \\
\end{array}$ & $\begin{array}{c}4.14 \\
1.55-7.57 \\
\end{array}$ & $\begin{array}{c}4.35 \\
2.35-7.53 \\
\end{array}$ \\
\hline P 15 & $\begin{array}{c}4.88 \\
3.75-5.87 \\
\end{array}$ & $\begin{array}{c}4.68 \\
3.73-5.34 \\
\end{array}$ & $\begin{array}{c}3.51 \\
2.57-4.41\end{array}$ & $\begin{array}{c}3.77 \\
2.89-4.34 \\
\end{array}$ & $\begin{array}{c}4.04 \\
1.66-7.05\end{array}$ & $\begin{array}{c}3.43 \\
1.89-4.70 \\
\end{array}$ \\
\hline P 16 & $\begin{array}{c}4.95 \\
3.81-6.45 \\
\end{array}$ & $\begin{array}{c}4.68 \\
3.35-6.31 \\
\end{array}$ & $\begin{array}{c}3.72 \\
2.56-4.91 \\
\end{array}$ & $\begin{array}{c}4.09 \\
3.05-5.77 \\
\end{array}$ & $\begin{array}{c}4.55 \\
2.26-7.54 \\
\end{array}$ & $\begin{array}{c}4.25 \\
1.43-13.73 \\
\end{array}$ \\
\hline P 17 & $\begin{array}{c}4.99 \\
3.57-5.90 \\
\end{array}$ & $\begin{array}{c}5.34 \\
4.29-6.71 \\
\end{array}$ & $\begin{array}{c}3.75 \\
3.01-5.17 \\
\end{array}$ & $\begin{array}{c}4.43 \\
3.60-5.57\end{array}$ & $\begin{array}{c}4.38 \\
1.09-6.81\end{array}$ & $\begin{array}{c}6.41 \\
2.70-11.29\end{array}$ \\
\hline P 18 & $\begin{array}{c}4.09 \\
2.97-5.12 \\
\end{array}$ & $\begin{array}{c}5.28 \\
4.56-6.14 \\
\end{array}$ & $\begin{array}{c}3.25 \\
2.41-4.05 \\
\end{array}$ & $\begin{array}{c}4.19 \\
3.27-5.95 \\
\end{array}$ & $\begin{array}{c}2.68 \\
1.06-5.17 \\
\end{array}$ & $\begin{array}{c}4.78 \\
2.76-8.91 \\
\end{array}$ \\
\hline P 19 & $\begin{array}{c}4.67 \\
3.66-6.33\end{array}$ & $\begin{array}{c}4.66 \\
4.00-5.60\end{array}$ & $\begin{array}{c}3.71 \\
2.61-4.87 \\
\end{array}$ & $\begin{array}{c}3.77 \\
3.34-4.12\end{array}$ & $\begin{array}{c}3.85 \\
1.19-7.92 \\
\end{array}$ & $\begin{array}{c}4.10 \\
2.60-6.37\end{array}$ \\
\hline P 20 & $\begin{array}{c}4.90 \\
3.43-6.22\end{array}$ & $\begin{array}{c}5.10 \\
3.77-6.59 \\
\end{array}$ & $\begin{array}{c}3.77 \\
3.13-4.67\end{array}$ & $\begin{array}{c}4.04 \\
3.20-4.52\end{array}$ & $\begin{array}{c}3.37 \\
1.55-6.12\end{array}$ & $\begin{array}{c}3.88 \\
1.76-6.81\end{array}$ \\
\hline Average & 5.03 & 5.18 & 3.94 & 4.17 & 4.34 & 4.92 \\
\hline Min. & 4.09 & 4.66 & 3.25 & 3.66 & 2.68 & 3.31 \\
\hline Max. & 5.52 & 5.68 & 5.89 & 5.07 & 6.34 & 7.24 \\
\hline Diference & 1.43 & 1.01 & 2.63 & 1.40 & 3.65 & 3.93 \\
\hline
\end{tabular}

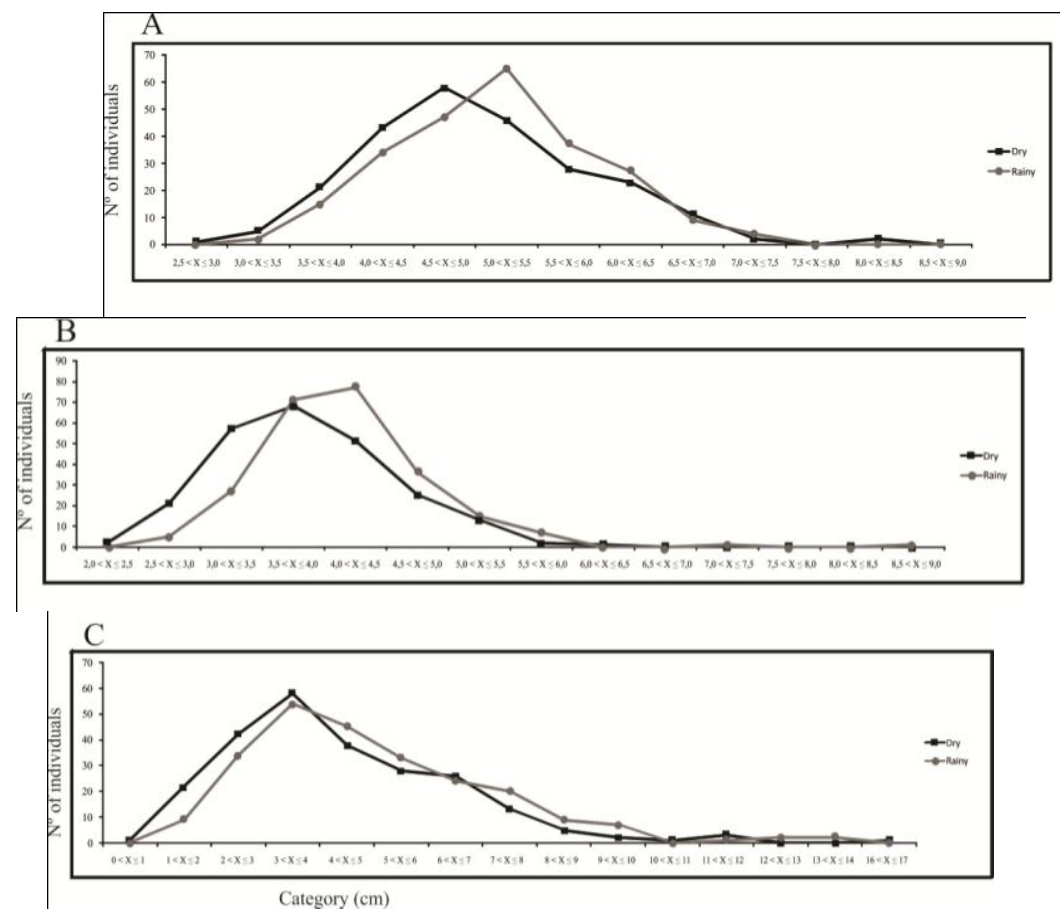

Figure 3. Distribution of length, width and weight frequencies of C. rhizophorae in São Paulo river estuary. 


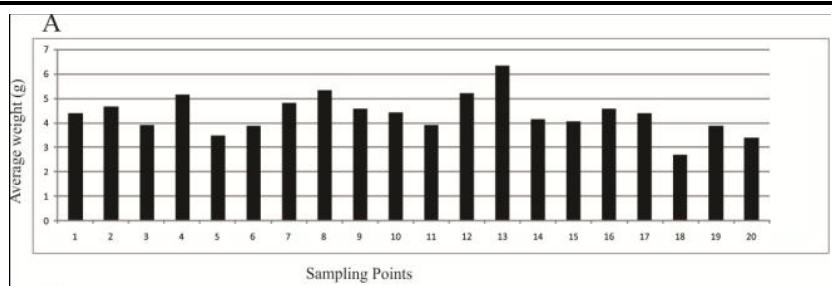

B

Sampling Points

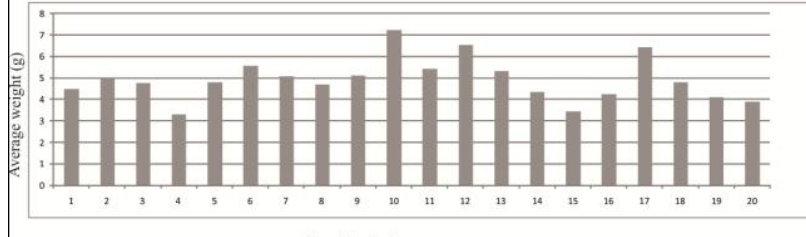

Sampling Points

Figure 4. Weight average of C. rhizophorae between sampled points in São Paulo river estuary.

The mean values for the metal concentration found in surface water, sediment, and mollusks, as well as the results of particle size, demonstrated that there were differences between the periods studied, as shown in table 3.

Table 3. Concentration of metals, organic matter (average, min., and max.), and particle size (Sand, Silt and Clay) of the São Paulo river estuary during dry and rainy seasons. Metals in water $\left(\mathrm{mg} \mathrm{l}^{-1}\right)$, metals in sediment and biota $\left(\mathrm{mg} \mathrm{kg}^{-1}\right)$, organic matter (O.M.\%) and sediment granulometry (\%).

\begin{tabular}{|c|c|c|c|c|c|c|}
\hline \multirow{3}{*}{ Variable } & \multicolumn{6}{|c|}{ Matrix / Season } \\
\hline & \multicolumn{2}{|c|}{ Water - Total } & \multicolumn{2}{|c|}{ Sediment } & \multicolumn{2}{|c|}{ Biota } \\
\hline & Dry & Rainy & Dry & Rainy & Dry & Rainy \\
\hline \multirow{2}{*}{$\mathbf{F e}$} & 1.95 & 1.03 & 6604.8 & 7213.74 & 169.67 & 271.84 \\
\hline & $0.46-8.63$ & $0.29-4.12$ & $2672.80-12635$ & $2625.10-13732.00$ & $89.93-404.87$ & $198.62-478.63$ \\
\hline \multirow{2}{*}{$\mathbf{Z n}$} & 0.05 & 0.04 & 14.24 & 15.97 & 1219.3 & 1378.19 \\
\hline & $0.03-0.10$ & $0.04-0.04$ & $7.09-21.06$ & $6.26-25.27$ & $622.40-1769.50$ & $1092.10-1801.20$ \\
\hline \multirow{2}{*}{ Mn } & 0.12 & 0.06 & 47.24 & 61.64 & 16.24 & 22.34 \\
\hline & $0.07-0.25$ & $0.02-0.19$ & $4.80-106.75$ & $0.12-103.21$ & $10.70-24.43$ & $0.59-28.94$ \\
\hline \multirow{2}{*}{$\mathbf{C u}$} & 0.11 & 0.03 & 13.04 & 14.48 & 296.48 & 203.76 \\
\hline & $0.07-0.20$ & $0.02-0.05$ & $5.29-24.25$ & $5.42-28.04$ & $168.95-396.48$ & $142.25-276.87$ \\
\hline \multirow{2}{*}{$\mathbf{N i}$} & 0.36 & 0.21 & 6.23 & 6.81 & 3.39 & 2.69 \\
\hline & $0.29-0.44$ & $0.08-0.32$ & $3.01-10.58$ & $2.62-14.44$ & $0.70-7.86$ & $0.40-5.48$ \\
\hline \multirow{2}{*}{ Al } & 3.49 & 3.06 & 3286.19 & 4206.78 & 71.89 & 199.11 \\
\hline & $1.35-11.56$ & $0.58-4.72$ & $960.82-7437.90$ & $1016.20-13620.00$ & $1.00-212.79$ & $58.49-510.60$ \\
\hline \multirow{2}{*}{ O.M. } & \multirow{2}{*}{$* *$} & \multirow{2}{*}{$* *$} & 3.95 & 13.07 & \multirow{2}{*}{$* *$} & \multirow{2}{*}{$* *$} \\
\hline & & & $1.27-8.82$ & $10.75-15.94$ & & \\
\hline \multirow{2}{*}{ Sand } & \multirow{2}{*}{$* *$} & \multirow{2}{*}{$* *$} & 64.94 & 59.68 & \multirow{2}{*}{$* *$} & \multirow{2}{*}{$* *$} \\
\hline & & & $52-86.95$ & $37.93-80.73$ & & \\
\hline \multirow{2}{*}{ Silt } & \multirow{2}{*}{$* *$} & \multirow{2}{*}{$* *$} & 16.8 & 20.87 & \multirow{2}{*}{$* *$} & \multirow{2}{*}{$* *$} \\
\hline & & & $9.93-30.16$ & $10.42-33.84$ & & \\
\hline \multirow{2}{*}{ Clay } & \multirow{2}{*}{$* *$} & \multirow{2}{*}{$* *$} & 18.24 & 19.44 & \multirow{2}{*}{$* *$} & \multirow{2}{*}{$* *$} \\
\hline & & & $1.43-30.01$ & $8.85-32.20$ & & \\
\hline
\end{tabular}

** Not Applicable

The metal concentrations in the surface water were higher in the dry season for $\mathrm{Fe}\left(8.63 \mathrm{mg}^{-1}\right), \mathrm{Zn}$ $\left(0.10 \mathrm{mg} \mathrm{l}^{-1}\right), \mathrm{Mn}\left(0.25 \mathrm{mg} \mathrm{l}^{-1}\right), \mathrm{Cu}\left(0.20 \mathrm{mg} \mathrm{l}^{-1}\right), \mathrm{Ni}\left(0.44 \mathrm{mg} \mathrm{l}^{-1}\right)$, and $\mathrm{Al}\left(11.56 \mathrm{mg} \mathrm{l}^{-1}\right)$, than during

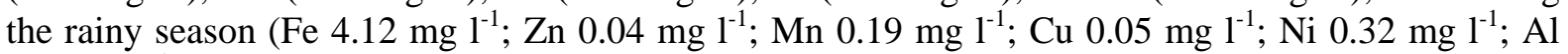
$\left.4.72 \mathrm{mg} \mathrm{l}^{-1}\right)$.

The metal concentrations of $\mathrm{Fe}\left(13.732 \mathrm{mg} \mathrm{kg}^{-1}\right), \mathrm{Zn}\left(25.27 \mathrm{mg} \mathrm{kg}^{-1}\right), \mathrm{Cu}\left(4.28 \mathrm{mg} \mathrm{kg}^{-1}\right), \mathrm{Ni}(14.44 \mathrm{mg}$ $\left.\mathrm{kg}^{-1}\right)$, and $\mathrm{Al}\left(13620 \mathrm{mg} \mathrm{kg}^{-1}\right)$ in the sediment, and of $\mathrm{Fe}\left(478.63 \mathrm{mg} \mathrm{kg}^{-1}\right), \mathrm{Zn}\left(1801.20 \mathrm{mg} \mathrm{kg}^{-1}\right), \mathrm{Mn}$ $\left(28.94 \mathrm{mg} \mathrm{kg}^{-1}\right)$, and $\mathrm{Al}\left(510.60 \mathrm{mg} \mathrm{kg}^{-1}\right)$ in the mollusks, were higher during the rainy season. However, concentrations of $\mathrm{Mn}\left(106.75 \mathrm{mg} \mathrm{kg}^{-1}\right)$ in the sediment and $\mathrm{Cu}\left(396.48 \mathrm{mg} \mathrm{kg}^{-1}\right)$ and $\mathrm{Ni}$ $\left(7.86 \mathrm{mg} \mathrm{kg}^{-1}\right)$ in mollusks were higher during the dry season.

The physicochemical parameters (temperature $\left({ }^{\circ} \mathrm{C}\right)$, salinity, $\mathrm{pH}$, dissolved oxygen $\left(\mathrm{mg} \mathrm{l}^{-1}\right)$, Eh $(\mathrm{mV})$ in water and $\mathrm{Eh}(\mathrm{mV})$ in sediments) also varied between both seasons (figure 2). For all parameters 
the values were higher in dry season, except for Eh. The mean temperature in the dry season was approximately $7^{\circ} \mathrm{C}$ higher than in the rainy season $\left(32.7^{\circ} \mathrm{C}\right.$ and $25.7^{\circ} \mathrm{C}$, respectively). The extreme values of temperatures were $31^{\circ} \mathrm{C}$ (minimum) and $35.4^{\circ} \mathrm{C}$ (maximum) during the dry season, and $24.9^{\circ} \mathrm{C}$ (minimum) and $27.3^{\circ} \mathrm{C}$ (maximum) during the rainy season. Although the highest values of $\mathrm{pH}$ occurred in the dry season, there was no considerable difference between both seasons. The maximum values in the dry season (8.04) and minimum in the rainy season (6.84) were close (Figure $5)$.
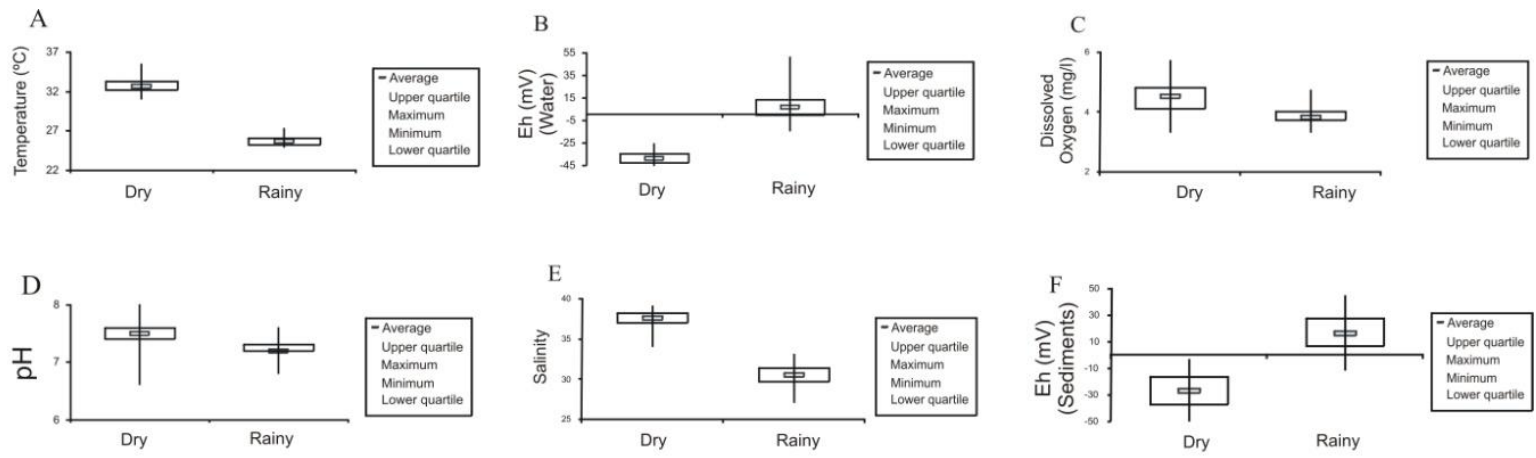

Figure 5. Representative Box Plots of the physical-chemical parameters in the estuary of the São Paulo river during the dry and rainy seasons: $(A)$ Temperature $\left({ }^{\circ} \mathrm{C}\right),(B)$ Eh $(\mathrm{mV})$ in water, $(C)$ Dissolved Oxygen, (D) $\mathrm{pH}$, $(E)$ Salinity, and $(F) E h(m V)$ in sediment.

In contrast to the $\mathrm{pH}$ results, Eh mean values in waters were noticeably different between the periods studied, ranging from -38.9 in the dry season to 6.3 in the rainy season (Figure 5). The dissolved oxygen, like the $\mathrm{pH}$, there was no difference in the values between the periods studied, the maximum value was $5.7 \mathrm{mg} \mathrm{l}^{-1}$ and $4.7 \mathrm{mg} \mathrm{l}^{-1}$ in the dry and rainy season respectively and the minimum of 3.3 $\mathrm{mg} \mathrm{L}^{-1}$ in both periods studied, however, the rainy season showed the lowest values.

The values of Eh in sediments showed similar behavior to values found in water. The lowest values, with the average of $-27 \mathrm{mV}$, in dry season indicate the reductive feature of mangrove environment, this is due to the fast consumption of oxygen by microbial species, once during the dry season there is a larger amount of dissolved oxygen (Figure 5).

About the content of total organic matter, in the dry season was higher than in the rainy season with 13.7 and 3.9 respectively (Table 3 ).

\section{DISCUSSION}

The average of extreme values for length in both season studied were $5.68 \mathrm{~cm}$ (maximum) in P06 during the rainy season and $4.09 \mathrm{~cm}$ (minimum) in P18 during the dry season (Figure 6). The difference of $1.59 \mathrm{~cm}$ between both periods can be considered as a significant value. If we compare with others studies with oysters (Nascimento et al., 1980; Cavalcanti, 2003; Harding, 2007), they also found differences of rate like that. With these results we can suggest that, in this case, the rainfall had effect on the oysters length.
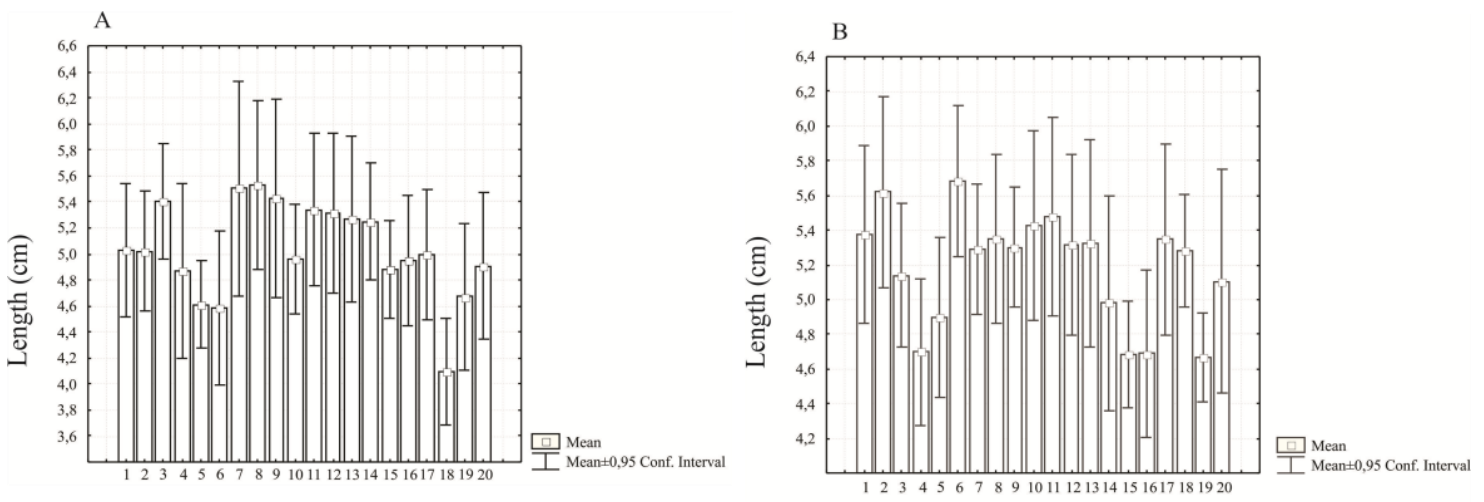

Sampling points

Figure 6. Average and confidence interval of length of C. rhizophorae in São Paulo river estuary. 
Analyzing the table 2, which shows the biometric data of the oysters in both season, we can see the average for the width and notice that the maximum value was $5.07 \mathrm{~cm}$ in point $\mathrm{P} 12$ during the rainy season and the minimum was $3.25 \mathrm{~cm}$ in point P18 during the dry season.

If we analyze the length between both seasons, we can notice that in mostly of points studied the mean values were higher in rainy season. But when we analyze the width we found 11 sampled points in rainy season with the mean values higher than dry season, so, we can't make any inference about the influence of seasonality on oysters width (Table 2). If we compare with the results found in studies with Crassostrea (Nascimento et al., 1980; Harding, 2007) they also found the similar results.

On the other hand when we compare the means of the values for weight tissue of the mollusks, we can notice one considerable difference of $4.56 \mathrm{~g}$ between the maximum average (in rainy season) in sampled point P10 with $7.24 \mathrm{~g}$ and the minimum value of $2.68 \mathrm{~g}$ in point P18 during the dry season (Table 2).

In this study we could identify that during the rainy season the $C$. rhizophorae in general had different sizes between both season studied, even that difference can be insignificant or so small. The fact was that during the rainy season the length, width and weight were higher than dry season.

When we analyze the physicochemical parameters The different values of surface water temperature, as well as the higher results during the dry season, can be explained by the different rainfall rates inherent to each season sampled, and the sunlight intensity, which is stronger in the dry season and directly influences the temperature rise.

Similarly to temperature, salinity is also directly related to rainfall rates, since the greater the water input in the region, the greater the salt dilution. The maximum value of salinity during the dry season was 39, which was observed at stations P09, P13, P14, and P20, while the maximum value during the rainy season was 33 , at stations $\mathrm{P} 01$ and $\mathrm{P} 02$.

Unlike the $\mathrm{pH}$ results, which did not present a considerable variation, the mean values of Eh ranged widely for the periods analyzed. These results suggest seasonal differences in the redox levels in this environment, with higher redox potential during the dry season. The mean Eh value of -38.9 during the dry season is an inherent characteristic of the mangrove ecosystem, due to the rapid oxygen consumption by microorganisms that decompose organic matter, which is abundant in this ecosystem (Carvalho, 2007).

Thus, the rainfall rates, which varied between the seasons, were decisive for the difference in results of the physicochemical parameters analyzed (Figure 5). This fact was also important for the difference found about the bioavailability in surface water and sediment as well as the metal concentration in the oysters tissue. Once these parameters are responsible for influencing the metal behavior in these matrices.

Concerning the study of metallic elements, the mean values for metals in surface water during the dry season were higher than the means in the rainy season. Thus, one can infer that this result is related to the fact that during the rainy season there is a higher rainfall, so that there is a greater dilution of metal concentrations in the water. However, in sediment and mollusks, the highest mean values were recorded in the rainy season (Table 3). These results are similar to the study by Vincente-Martorell et al. (2009), in which metals concentrations in water and sediment also varied between different seasons in a polluted estuary in Huelva region, Spain. However these results contrast with the research made by Weber et al. (2013), in this case, there wasn't difference in metals concentrations between seasons analyzed in water, sediment and biota in a Brazilian river. This situation shows that the concentrations of metals in estuarine regions may change between different seasons throughout the year depending on local conditions.

The metal behavior levels in mollusks were different the periods studied. Others authors found similar results about metal concentration in mollusks (Páez-Osuna et al., 1995; Ruelas-Inzunza and PáezOsuna, 2000). Which shows the importance of make seasonality studies when the focus are metal concentration in aquatic organisms, mainly when some animals are consumed by local communities and also can be distributed commercially.

In this study the highest means of the values found in the C. rhizophorae were recorded in the rainy season, except for $\mathrm{Ni}$ and $\mathrm{Cu}$, which had the opposite behavior (Table 3). But is also important 
mention that the metals concentration had variation along the sampling points, specially for the $\mathrm{Fe}, \mathrm{Al}$ and $\mathrm{Mn}$. The main significant difference was found for Mn during the rainy season, that in stations P04 and P05 the values found was $1.57 \mathrm{mg} \mathrm{kg}^{-1}$ and $0.59 \mathrm{mg} \mathrm{kg}^{-1}$ respectively, very different from the others, in what the average was $22.34 \mathrm{mg} \mathrm{kg}^{-1}$.

For the sediments the results were similar, but in this case the means values during the rainy season were higher for all metals (Table 3). Vincente-Martorell et al. (2009), who also carried out studies about metal variation between seasons in Spain, found similar results. Analyzing the metal behavior we can see that there was a little difference for the periods studied (Fig. 7A and B). The PCA (Principal Component Analysis) showed a strong association among $\mathrm{Cu}, \mathrm{Fe}, \mathrm{Ni}$ and $\mathrm{Zn}$ and a close association among them and organic matter.

The relationship between the particle size and the metals also varied. During the dry season, the particle size that showed close association with all metals, except for the Mn, was the clay (Fig. 7A). But in the rainy season, it was silt particle size that showed a moderate association for the same metals (Fig. 7B).
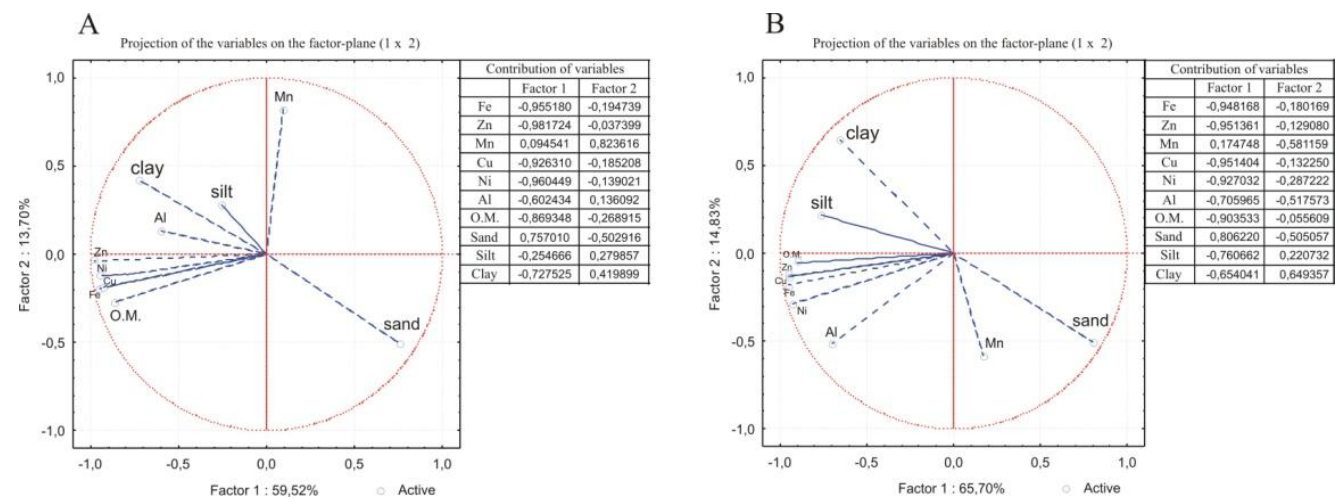

Figure 7. (A) Principal Component Analysis of metal concentrations in estuarine sediments of the São Paulo river during the dry season and $(B)$ during the rainy season.

Is important mention that the metal concentrations along the sampling points during one same season also varied, mainly for the Mn (Table 3). As well as the biometric data of C. rhizophorae also varied along the São Paulo river estuary.

The highest values of metal concentrations in surface water in the estuary were recorded during the dry season. These outcomes are related to the rainfall, since this factor was essential for the variation of physicochemical parameter mean values and during the rainy season, the volume of rainfall contributed for the dilution of the metal concentration in the surface waters, thus influencing metal behavior and bioavailability in this matrix. In the Table 3, we can observe that there was metals concentration variation along the estuary, the $\mathrm{Fe}$ and $\mathrm{Al}$ showed a large variation in both season, mainly at station P20, close to the residences of the area. This situation may indicate a possible source of anthropogenic contamination.

Analyzing the metal concentrations in surface water, sediments and mollusks and comparing with the growth, we can make some inference about the relationship of the essential elements and the living cycle of $C$. rhizophorae.

According the results, we could noticed that the element zinc had some effect on the mollusks behavior. As we know, $\mathrm{Zn}$ is important for the develop of many organisms (Brzoska and MoniuszkoJakoniuk, 2001), and if we compare the zinc concentration and tissue weight of $C$. rhizophorae in this study, there was a relationship between these parameters (Table 4). In both seasons the tissue weight was higher than $4.0 \mathrm{~g}$ when the $\mathrm{Zn}$ concentration was higher than $1000 \mathrm{mg} \mathrm{kg}^{-1}$, except for the sampling points P06, P11, P14 and P18 in dry season, and P04, P15 and P20 during rainy season.

Table 4. Relationship between the metal concentration $\left(\mathrm{mg} \mathrm{kg}^{-1}\right)$ and biometric data (Length and width in $\mathrm{cm}$ and Weight in $g$ ) of C. rhizophorae in São Paulo river estuary in dry and rainy.

\begin{tabular}{|c|c|c|c|c|c|c|c|c|c|}
\hline & \multicolumn{6}{|c|}{ Metals (dry season) } & \multicolumn{3}{|c|}{ Oysters Biometric data (dry season) } \\
\hline $\begin{array}{c}\text { Sampling } \\
\text { points }\end{array}$ & $\mathbf{F e}$ & Zn & Mn & $\mathrm{Cu}$ & $\mathbf{N i}$ & Al & Length & Width & Weight \\
\hline P 01 & 404.87 & 1388.62 & 24.43 & 39.18 & $<\mathrm{LDM}$ & 200.44 & 5.03 & 3.87 & 4.37 \\
\hline
\end{tabular}


Biometric Aspects and Seasonal Metal Concentration in Crassostrea rhizophorae in São Paulo River Estuary, Brazil

\begin{tabular}{|c|c|c|c|c|c|c|c|c|c|}
\hline P 02 & 125.36 & 1096.61 & 12.17 & 318.81 & $<\mathrm{LDM}$ & $<\mathrm{LDM}$ & 5.02 & 4.33 & 4.64 \\
\hline P 03 & 135.17 & 971.94 & 17.76 & 319.18 & $<\mathrm{LDM}$ & $<\mathrm{LDM}$ & 5.40 & 3.73 & 3.88 \\
\hline P 04 & 144.64 & 1182.54 & 12.05 & 304.50 & $\angle \mathrm{LDM}$ & $<\mathrm{LDM}$ & 4.86 & 4.22 & 5.13 \\
\hline P 05 & 89.93 & 622.40 & 10.70 & 168.95 & $<\mathrm{LDM}$ & $<\mathrm{LDM}$ & 4.61 & 3.37 & 3.47 \\
\hline P 06 & 140.55 & 1185.39 & 17.59 & 293.47 & 6.06 & $<\mathrm{LDM}$ & 4.58 & 5.89 & 3.87 \\
\hline P 07 & 147.86 & 1140.29 & 18.29 & 240.27 & 5.60 & $<\mathrm{LDM}$ & 5.50 & 3.96 & 4.80 \\
\hline P 08 & 112.14 & 1205.32 & 17.71 & 259.25 & 7.86 & $<\mathrm{LDM}$ & 5.52 & 3.83 & 5.32 \\
\hline P 09 & 150.74 & 1441.84 & 16.43 & 290.98 & 5.22 & $<\mathrm{LDM}$ & 5.42 & 4.01 & 4.56 \\
\hline P 10 & 154.75 & 1389.10 & 17.99 & 255.27 & $<\mathrm{LDM}$ & $<\mathrm{LDM}$ & 4.96 & 3.95 & 4.41 \\
\hline P 11 & 354.39 & 1394.05 & 19.34 & 283.61 & 1.39 & 212.79 & 5.33 & 3.79 & 3.90 \\
\hline P 12 & 202.06 & 1769.47 & 14.69 & 281.48 & 1.05 & 1.91 & 5.31 & 3.83 & 5.19 \\
\hline P 13 & 141.13 & 1617.56 & 11.92 & 307.08 & $<\mathrm{LDM}$ & $<\mathrm{LDM}$ & 5.26 & 4.13 & 5.29 \\
\hline P 14 & 141.75 & 1159.21 & 14.11 & 281.21 & $<\mathrm{LDM}$ & 26.09 & 5.24 & 4.19 & 3.82 \\
\hline P 15 & 138.06 & 1249.32 & 12.15 & 355.71 & $<\mathrm{LDM}$ & $<\mathrm{LDM}$ & 4.88 & 3.51 & 4.04 \\
\hline P 16 & 138.10 & 1231.34 & 17.43 & 368.50 & 1.58 & $<\mathrm{LDM}$ & 4.95 & 3.72 & 4.55 \\
\hline $\mathrm{P} 17$ & 132.47 & 1247.63 & 13.65 & 297.01 & $<\mathrm{LDM}$ & 1.00 & 4.99 & 3.75 & 4.38 \\
\hline P 18 & 164.00 & 1203.57 & 16.61 & 396.48 & 0.70 & 24.86 & 4.09 & 3.25 & 2.68 \\
\hline P 19 & 179.49 & 978.24 & 19.36 & 293.62 & 1.73 & 23.96 & 4.67 & 3.71 & 3.85 \\
\hline P 20 & 196.05 & 911.63 & 20.51 & 285.05 & 2.74 & 84.12 & \begin{tabular}{l|l}
4.90 \\
\end{tabular} & \begin{tabular}{|l|l|}
3.77 \\
\end{tabular} & 3.37 \\
\hline & \multicolumn{6}{|c|}{ Metals (rainy season) } & \multicolumn{3}{|c|}{$\begin{array}{c}\text { Oysters Biometric data (rainy } \\
\text { season) }\end{array}$} \\
\hline $\begin{array}{l}\text { Sampling } \\
\text { points }\end{array}$ & $\mathbf{F e}$ & $\mathbf{Z n}$ & Mn & $\mathbf{C u}$ & $\mathbf{N i}$ & Al & Length & Width & Weight \\
\hline P 01 & 210.95 & 1092.14 & 21.94 & 204.25 & 0.89 & 125.62 & 5.37 & 4.44 & 4.49 \\
\hline $\mathrm{P} 02$ & 204.11 & 1347.93 & 27.70 & 192.41 & 1.30 & 123.31 & 5.61 & 3.95 & 5.00 \\
\hline P 03 & 230.83 & 1188.31 & 22.52 & 169.75 & $<\mathrm{LDM}$ & 153.72 & 5.14 & 4.28 & 4.76 \\
\hline P 04 & 198.62 & 1179.59 & 1.57 & 204.96 & 1.38 & 72.41 & 4.69 & 3.66 & 3.31 \\
\hline $\mathrm{P} 05$ & 266.88 & 1358.73 & 0.59 & 225.56 & 0.40 & 244.36 & 4.89 & 4.11 & 4.80 \\
\hline P 06 & $380, .70$ & 1801.18 & 23.64 & 209.79 & 2.56 & 235.84 & 5.68 & 3.98 & 5.56 \\
\hline $\mathrm{P} 07$ & 247.05 & 1343.15 & 24.37 & 187.11 & $<\mathrm{LDM}$ & 186.71 & 5.29 & 4.21 & 5.06 \\
\hline P 08 & 227.03 & 1249.27 & 22.03 & 183.41 & 3.92 & 60.47 & 5.34 & 4.34 & 4.68 \\
\hline P 09 & 316.08 & 1637.66 & 27.19 & 276.87 & 2.44 & 183.30 & 5.30 & 3.94 & 5.12 \\
\hline P 10 & 232.21 & 1283.59 & 22.24 & 196.58 & 0.50 & 168.60 & 5.42 & 4.31 & 7.24 \\
\hline P 11 & 272.80 & 1771.39 & 28.94 & 172.10 & 2.85 & 165.57 & 5.48 & 4.43 & 5.41 \\
\hline P 12 & 478.63 & 1787.32 & 26.41 & 241.75 & 2.65 & 510.60 & 5.31 & 5.07 & 6.55 \\
\hline P 13 & 258.05 & 1554.71 & 26.17 & 247.60 & 1.60 & 148.57 & 5.32 & 4.21 & 5.31 \\
\hline P 14 & 346.94 & 1231.05 & 26.86 & 142.25 & 4.41 & 313.73 & 4.98 & 4.16 & 4.35 \\
\hline P 15 & 287.98 & 1294.64 & 26.97 & 196.45 & 3.27 & 299.98 & 4.68 & 3.77 & 3.43 \\
\hline P 16 & 232.62 & 1564.97 & 25.79 & 224.71 & 5.48 & 58.49 & 4.68 & 4.09 & 4.25 \\
\hline P 17 & 342.26 & 1300.65 & 21.86 & 169.96 & 3.56 & 400.67 & 5.34 & 4.43 & 6.41 \\
\hline P 18 & 207.17 & 1194.17 & 22.34 & 171.85 & 4.82 & 86.12 & 5.28 & 4.19 & 4.78 \\
\hline P 19 & 245.76 & 1217.77 & 24.77 & 242.70 & 2.86 & 282.52 & 4.66 & 3.77 & 4.10 \\
\hline P 20 & 250.25 & 1165.70 & 23.01 & 215.21 & 3.63 & 161.70 & 5.10 & 4.04 & 3.88 \\
\hline
\end{tabular}

On the other hand, we couldn't identified a relationship between the $\mathrm{Zn}$ concentrations and the results for length and width of the oysters. This situation indicates that the element $\mathrm{Zn}$ has influence on the oysters tissue weight. Even if we have not seen connection among $\mathrm{Zn}$ concentration and length and width of the oysters.

Considering the iron concentrations in mollusks and all biometric data (Table 4) we can identify that during the rainy season the average concentration of Fe was higher than dry season, and all biometric average values (length, width and weight) followed this situation. Many animals use the element Fe as essential micronutrient to regulate metabolic processes during their developing (Brzoska and Moniuszko-Jakoniuk, 2001), therefore we can infer that in this study, the Fe had influence on oysters behavior.

Similar to the iron, the concentration levels for $\mathrm{Mn}$ and $\mathrm{Al}$ and biometric average rate in mollusks had the same behavior. With length, width and weight values higher during rainy season, following the highest values for $\mathrm{Mn}$ and $\mathrm{Al}$ also in rainy season. But this situation not happened for $\mathrm{Cu}$ and $\mathrm{Ni}$ (Table 4).

In Brazil, there is no institutional organizations with guidelines to specify maximum limits for metal concentrations in bivalve mollusks, for this reason, comparison was made with the Certifed Reference Materials developed by National Institute of Standards and Technology (NIST), USA (Table 5). According to comparisons, the elements $\mathrm{Fe}$ and $\mathrm{Cu}$ are out of the limits. The element Al showed an 
average out of normality in dry season, therefore, the values were normal in some sampled points. This situation causes difficulty in determining the level of real impact of these elements in São Paulo river estuary.

Table 5. Maximum concentrations of metals in waters $\left(m g l^{-1}\right)$, sediments $\left(m g \mathrm{~kg}^{-1}\right)$ and mollusks $\left(m g \mathrm{~kg}^{-1}\right)$ established by national and international institutions.

\begin{tabular}{|l|c|c|c|c|c|c|c|}
\hline \multirow{2}{*}{ Institutions } & \multicolumn{7}{|c|}{ Metals/Values } \\
\cline { 2 - 8 } & & $\mathrm{Fe}$ & $\mathrm{Zn}$ & $\mathrm{Mn}$ & $\mathrm{Cu}$ & $\mathrm{Ni}$ & $\mathrm{Al}$ \\
\hline CONAMA & Water & 0.3 & 0.09 & 0.1 & 0.005 & 0.025 & 1.5 \\
\hline NOAA & Sediment & $18.84 \%$ & 0.098 & 0.63 & 0.028 & 0.019 & $2.55 \%$ \\
\hline NIST & mollusks & $205.8 \pm 6.8$ & $1424 \pm 46$ & $18.5 \pm 0.2$ & $71.6 \pm 1.6$ & $1.04 \pm 0.09$ & $197.2 \pm 6$ \\
\hline
\end{tabular}

CONAMA: Brazilian National Environment Council.

NOAA: National Oceanic Atmospheric Administration, USA (O'Connor, 1998).

NIST: National Institute of Standards and Technology, USA.

\section{CONCLUSiOnS}

It is clearly evident from the studies of many authors that seasonality has influence on the bioavailability and bioconcentration of metals in surface waters, sediments and organisms. In this study The different rainfall rates between the seasons affected the results for the variables studied. Different values and concentrations between sampling periods can lead to misinterpretation of results. The results revealed the existence of seasonal differences in the variables studied in the estuary of the São Paulo river, since rainfall played a decisive role in the physicochemical parameter values. Changes in the mean values of these parameters throughout the seasons have generated variations in metal bioavailability in surface water and in the sediment. This bioavailability directly influenced the metal concentrations recorded in Crassostrea rhizophorae.

Considering the metal concentrations in surface water, the difference in rainfall between the dry and rainy seasons was essential for there to be a difference in the mean levels of metal bioavailability that was studied. For the sediment and mollusks, the seasonal variation also influenced the difference between the metal bioavailability and bioconcentration levels that were analyzed, with the highest mean values recorded in the rainy season, except for $\mathrm{Cu}$ and $\mathrm{Ni}$ in the bivalves. Therefore, we can infer that different rainfall rates between seasons can change the values of parameters along estuarine zones.

The difference found from the biometric data in this study can be considered as significant, since these animals are small organisms. The concentration of essential elements $\mathrm{Zn}, \mathrm{Fe}$ and $\mathrm{Mn}$ in mollusks studied in this research had influence for the difference found about biometric data between the dry and rainy season.

Further investigations will be carried out, with additional studies, including research with other species of mollusks, in this and nearby regions to make comparisons between the results and be able to issue more complete statements about the bioavailability and bioconcentration of metals in estuarine environments.

\section{ACKNOWLEDGMENTS}

Alexandre D. D. Milazzo received a Master grant from Coordenação de Aperfeiçoamento de Pessoal de Nível Superior (CAPES). Thanks are due to POSPETRO / UFBA technicians for all laboratory assistance.

\section{REFERENCES}

ASTM - American Society for Testing and Materials. D3974-1981 standard practice for extraction of trace elements from sediments, West Conshohocken, PA, (2008).

Boyden, C.R. Trace element content and body size in molluscs. Nature. 251, Pp.311-314, (1974).

Brzóska, M.M. and Moniuszko-Jakoniuk, J. Interactions between cadmium and zinc in the organism. Food and Chemical Toxicology. 39, Pp.967-980, (2001).

Campana, O., Rodríguez, A. and Blasco, J. Bioavailability of heavy metals in the Guadalete River Estuary (SW Iberian Peninsula). Ciências Marinas. 31(1B), Pp 135-147, (2005). 
Carvalho, L.V.M.de. Estudo da qualidade da água superficial em zona estuarina do rio São Paulo - Região de Candeias - BA. MSc. Thesis, Graduate Course in Geociences, Federal Universityof Bahia, Pp.129, (2007).

Cavalcanti, A.D. Monitoramento da contaminação por elementos-traço em ostras comercializadas em Recife, Pernambuco, Brasil. Caderno Saúde Pública. 19(5), Pp 1545-1551, (2003).

Harding, J.M. Comparison of growth rates between diploid deby eastern oysters (crassostrea virginica, gmelin 1791), triploid eastern oysters, and triploid suminoe oysters (C. ariakensis, Fugita, 1913). Journal of Shellfish Research. 26(4), Pp 961-972, (2007).

Jesus, H.C., Fernandes, L.F.L., Zandonade, E., Anjos Jr., E.E., Gonçalves, R.F., Marques, F.C., Reis, L.A., Romano, C.T., Teixeira, R.D. and Santos Sad, CM. Avaliação da contaminação por metais pesados em caranguejos e sedimentos de áreas de manguezal do sistema estuarino de Vitória - ES. Technical Report Project Facitec/PMV-ES, contract number 4985717/2001, 40, (2003).

Jesus, R.S.de. Metais traço em sedimentos e no molusco bivalve Anomalocardia brasiliana (Gmelin, 1791), municípios de madre de deus e de Saubara, Bahia. MSc. Thesis, Graduate Course in Geociences, Federal Universityof Bahia, 101, (2011).

Kirimurê. [online] http://www.btsinstitutokirimure.ufba.br/?p=4.htm/ (Accessed 6 June 2015).

Nascimento, I.A., Pereira, S.A. and Souza, R.C. Determination of the optimum commercial size for the mangrove oyster (Crassostrea rhizophorae) in Todos os Santos Bay, Brazil. Aquaculture. 20, Pp 1-8, (1980).

Nizoli, E.C. and Luiz-Silva, W. O papel dos sulfetos volatilizados por acidificação no controle do potencial de biodisponibilidade de metais em sedimentos contaminados de um estuário tropical, no sudeste do Brasil. Química Nova. 32(2), Pp 365-372, (2009).

Onofre, C.R.E., Celino, J.J., Nano, R.M.W. and Queiroz, A.F.S. Biodisponibilidade de metais traços nos sedimentos de manguezais da porção norte da Baía de Todos os Santos, Bahia, Brasil. Revista de Biologia e Ciências da Terra. 7(2), Pp 65-82, (2007).

Páez-Osuna, F., Frías-Espericueta, M.G. and Osuna-López, J.I. Trace Metal Concentrations in Relation to Season and Gonadal Maturation in the Oyster Crassostrea iridescens. Marine Environmental Research. 40(1), Pp 19-31, (1995).

Phillips, D.J. Biological indicator organisms monitor metal pollution. Environmental Pollution. 13, Pp 281-317, (1977).

Quayle, D.B. Pacific Oyster Culture in British Columbia. Bulletin of the Fisheries Research Board of Canada. 169, Pp 193, (1969).

Ruelas-Inzunza, J.R. and Páez-Osuna, F. Comparative bioavailability of trace metals using three filter-feeder organisms in a subtropical coastal environment (Southeast Gulf of California). Environmental Pollution. 107, Pp 437-444, (2000).

Shulkin, V.M., Presley, B.J. and Kavun, V.Ia. Metal concentrations in mussel Crenomytilus grayanus and oyster Crassostrea gigas in relation to contamination of ambient sediments. Environment International. 29, Pp 493-502, (2003).

Silva, C.A.E., Smith, B.D. and Rainbow, P.S. Comparative biomonitors of coastal trace metal contamination in tropical South America (N. Brazil). Marine Environmental Research. 61, Pp 439-455, (2006).

Strady, E., Schäfer, J., Baudrimont, M. and Blnc, G. Tracing cadmium contamination kinetics and pathways in oysters (Casostera gigas) by multiple stable $\mathrm{Cd}$ isotope spike experiments. Ecotoxicology and Environmental Safety. 74(4), pp.600 - 606. . (2011)

Vincente-Martorell, J.J., Galindo-Riaño, M.D., Garcia-Vargas, M. and Granado-Castro, M.D. Bioavailability of heavy metals monitoring water, sediments and fish species from a polluted estuary. Journal of Hazardous Materials, Vol. 162, Pp 823-836, (2009).

Weber, P., Behr, E.R., Knorr, C.D.L., Vendruscolo, D.S., Flores, E.M.M., Dressler, V.L. and Baldisserotto, B. Metals in water, sediment, and tissues of two species from different trophic levals in a subtropical Brazilian river. Microchemical Journal. 106, Pp 61-66, (2013).

Citation: A. D. Daltro Milazzo et al., "Biometric Aspects and Seasonal Metal Concentration in Crassostrea rhizophorae in São Paulo River Estuary, Brazil ", International Journal of Research in Environmental Science, vol. 4, no. 2, p. 22-34, 2018. http://dx.doi.org/ 10.20431/2454-9444.0402003

Copyright: (C) 2018 A. D. Daltro Milazzo et al., This is an open-access article distributed under the terms of the Creative Commons Attribution License, which permits unrestricted use, distribution, and reproduction in any medium, provided the original author and source are credited. 